\title{
TìNH TRẠNG DINH DƯỠNG VÀ THỰC TRẠNG NUÔI DƯỠNG CỦA BỆNH NHÂN SUY TIM CÁP TẠI VIẸN TIM MẠCH VIẸT NAM 2020
}

Nguyễn Thị Huế ${ }^{1, ®}$, Phạm Minh Tuấn ${ }^{1,2}$

${ }^{1}$ Bệnh viện Bạch Mai

${ }^{2}$ Trường Đại học Y Hà Nội

Tình trạng dinh dương của bệnh nhân suy tim cấp ảnh hưởng đến việc điều trị và phương pháp nuôi dưỡng trong thời gian nằm viện. Nghiên cứu trên 103 bệnh nhân, khi nhập viện tỷ lệ SDD theo BMI chung là 20,4\%, ở nhóm suy tim cấp không phù SDD chiếm $20 \%$ (nam 22,2\% cao hơn nữ là 15,4\%). Tỷ lệ nguy cơ dinh dưỡng cao theo thang điểm mNUTRIC là 35,9\%, tỷ lệ nguy cơ cao ở nam (30,3\%) thấp hơn ở nữ (45,9\%) sự khác biệt không có ý nghĩa thống kê $(p<0,05)$. Trong 1 tuần nằm viện bệnh nhân giảm nhiều nhất $8 \mathrm{~kg}$ và tăng nhiều nhất $7,3 \mathrm{~kg}$. Gián đoạn nuôi dưỡng chiếm 60,2\%. Lý do gây gián đoạn cao nhất là tồn dư dịch dạ dày cao chiếm 33,9\%, làm thủ thuật chiếm 26,2\%. Khẩu phần ăn: Năng lượng thực tế đạt được cao nhất chiếm 66,5\% lượng cung cấp. Tỷ lệ bệnh nhân đạt mức năng lượng 25 - $30 \mathrm{kcal} / \mathrm{kg} / \mathrm{ngày}$ thấp nhất vào ngày đầu tiên (6,8\%), cao nhất vào ngày thứ 7 (17,2\%). Cần chú ý đánh giá TTDD và khẩu phần ăn, gián đoạn nuôi dướng để có biện pháp can thiệp kịp thời.

Từ khóa: Suy tim cấp, suy dinh dưỡng, mNutric score, BMI

\section{I. ĐẠT VẤN ĐỀ}

Suy tim là một hội chứng lâm sàng đặc trưng bởi các triệu chứng điển hình (khó thở, phù chân và mệt mỏi) mà có thể đi kèm với các dấu hiệu (tĩnh mạch mạch cổ nổi, ran phổi và phù ngoại vi) gây ra bởi bất thường cấu trúc và/hoặc chức năng tim mạch, dẫn đến cung lượng tim giảm và/hoặc áp lực trong tim cao lúc nghỉ hoặc khi gắng sức/tress. ${ }^{1}$ Suy tim cấp tính (AHF) được đặc trưng bởi các triệu chứng và dấu hiệu suy tim nhanh chóng cần điều trị khẩn cấp, thường xuyên phải nhập viện. Các hướng dẫn gần đây nhận ra rằng các bệnh nhân $A H F$ có thể không có tiền sử suy tim trước đó và do đó là các trường hợp khởi phát mới (de novo). ${ }^{2}$ Tiên lượng của bệnh nhân mắc AHF vẫn còn kém. Tỷ lệ tử vong tại bệnh viện cao tới 5 - 10\% và khoảng $25 \%$ bệnh nhân tử vong trong năm đầu tiên sau khi nhập viện. ${ }^{3}$ Suy tim

Tác giả liên hệ: Nguyễn Thị Huế

Bệnh viện Bạch Mai

Email: Huenguyen296.hmu@gmail.com

Ngày nhận: 15/09/2021

Ngày được chấp nhận: 25/10/2021 cấp tính là nguyên nhân đầu tiên của việc nhập viện ở người cao tuổi ở các nước phương Tây, mặc dù có những tiến bộ trong điều trị về y tế và thiết bị nhưng vẫn có tỷ lệ mắc bệnh và tử vong cao. Suy tim cấp đại diện cho một vấn đề sức khỏe cộng đồng lớn, gánh nặng tài chính lớn và thách thức đối với nghiên cứu tim mạch hiện tại. ${ }^{4}$ Theo tác giả Agra Bermejo và cộng sự (2017) Suy dinh dưỡng thường gặp ở bệnh nhân nhập viện vì suy tim (HF). Nó dường như là một trung gian của sự tiến triển bệnh và xác định tiên lượng xấu, đặc biệt là trong giai đoạn suy tim tiến triển. ${ }^{5}$ Trên thế giới đã có nhiều nghiên cứu về tình trạng dinh dưỡng của người bệnh suy tim cấp. Tuy nhiên, cho đến nay tại Viện Tim Mạch Việt Nam vẫn chưa có báo cáo cụ thể nào về tình trạng dinh dưỡng và thực trạng nuôi dưỡng của các bệnh nhân suy tim cấp trong quá trình điều trị, đặc biệt là các bệnh nhân suy tim cấp nặng, hồi sức phải đặt ống nội khí quản, thở máy, phải ăn qua sonde dạ dày hoặc nuôi dưỡng tĩnh mạch. Xuất phát từ thực tiễn trên nên chúng tôi tiến hành nghiên cứu 
tình trạng dinh dưỡng và thực trạng nuôi dưỡng của bệnh nhân suy tim cấp tại Viện Tim Mạch Việt Nam năm 2020 với mục tiêu:

1. Đánh giá tình trạng dinh dưỡng lúc nhập viện của bệnh nhân suy tim cấp tại Viện Tim Mạch Việt Nam 2020.

2. Mô tả thực trạng nuôi dưỡng của bệnh nhân suy tim cấp tại Viện Tim Mạch Việt Nam 2020.

\section{II. ĐÓI TƯỢNG VÀ PHƯƠNG PHÁP}

\section{1. Đối tượng}

Bệnh nhân điều trị nội trú tại khoa Cấp cứu và Hồi sức tích cực Viện Tim Mạch từ 11/2020 đến 6/2021.

Tiêu chuẩn lựa chọn: Người bệnh vào viện được chẩn đoán suy tim cấp (AHF) theo tiêu chuẩn của ESC 2016.

- Người bệnh có thời gian nằm viện trên 5 ngày.

- Bệnh nhân từ 18 tuổi trở lên.

- Bệnh nhân đồng ý tham gia vào nghiên cứu, cung cấp đủ thông tin.

- Bệnh nhân hôn mê: Được sự đồng thuận của người nhà, người giám hộ.

- Bệnh nhân có thời gian nằm viện trên 5 ngày.

Tiêu chuẩn loại trù:

- Bệnh nhân nằm viện dưới 5 ngày.

- Bệnh nhân bị loạn thần, người nhà không nắm được tình hình hình và không khai thác được thông tin.

- Bệnh nhân cụt 2 chi trên hoặc 2 chi dưới hoặc không đo được các chỉ số nhân trắc.

- Bệnh nhân là đối tượng trong nghiên cứu này từ các lần nhập viện trước.

\section{Phương pháp}

Thời gian và địa điểm nghiên cứru: Từ tháng 11/2020 - 6/2021 tại khoa cấp cứu và hồi sức tích cực Viện Tim Mạch Việt Nam.

Thiết kế nghiên cứru: Mô tả cắt ngang có theo dõi dọc.

Phương pháp chọn mẫu và cỡ mẫu nghiên cứu: Chọn mẫu thuận tiện, tất cả bệnh nhân nằm điều trị nội trú tại bệnh viện trong thời gian tiến hành nghiên cứu và thoả mãn tiêu chuẩn lựa chọn nêu trên đều được chọn vào nghiên cứu. Có 197 bệnh nhân đủ tiêu chuẩn, tuy nhiên xin về, tử vong thời gian nằm tại viện ngắn dưới 5 ngày nên chỉ còn 103 bệnh nhân.

\section{Chỉ số nghiên cứu:}

- Thông tin chung về nhân khẩu: Tuổi, giới.

- Tỷ lệ \% SDD theo phân loại BMI lúc nhập viện: BMI tính theo công thức:Cân nặng/(chiều cao). ${ }^{2}$ Nếu không cân được do cấp cứu thủ thuật thì sử dụng công thức ước tính BMI từ chu vi vòng cánh tay: $\mathrm{BMI}=0,873 \times \operatorname{MUAC}(\mathrm{cm})-0,042 .{ }^{6}$

- Nguy cơ dinh dưỡng theo Nutric score gồm: tuổi, số bệnh kèm theo, số ngày nằm viện cho tới khi vào khoa ICU, tổng điểm đánh giá mức độ nặng của bệnh APACHE II và điểm đánh giá suy tạng (SOFA) trong 24 giờ kể từ khi nhập viện.

- Tỷ lệ \% các đường nuôi dưỡng.

- Gián đoạn nuôi dưỡng là khi không được cung cấp bữa ăn do nguyên nhân nào đó. Các lí do sảy ra làm bệnh nhân bị cho nhịn ăn.

- Năng lượng cung cấp từ protein, lipid, glucid theo khẩu phần $24 \mathrm{~h}$ trong 1 tuần nằm viện. Tỷ \% người bệnh ăn đạt NCKN: Về năng lượng

Thu thập số liệu: Theo hồ sơ bệnh án, phiếu theo dõi nuôi ăn và ghi chép khẩu phần 24h cho bệnh nhân. Khẩu phần qua đường miệng và ống thông: tất cả các sản phẩm bệnh nhân ăn trong ngày, số lượng trong mỗi bữa, cả ngày, công thức từ nhãn sản phầm và từ khoa dinh dưỡng. Khẩu phần tĩnh mạch : tất cả các dịch nuôi dưỡng tĩnh mạch thu thập từ bệnh án

\section{Phân tích số liệu}

Phần mềm Excell, SPSS 20,0. Dùng $T$ - test để so sánh 2 tỷ lệ, mức ý nghĩa $p<0,05$.

\section{4. Đạo đức trong nghiên cứu}

Điều tra đối tượng trên tinh thần tự nguyện, 
đồng ý cộng tác, không ép buộc và trên tinh thần tôn trọng. Mọi thông tin về đối tượng được giữ bí mật và chỉ sử dụng cho mục đích nghiên cứu. Nghiên cứu được sự chấp thuận của lãnh đạo Viện Tim Mạch Việt Nam. Nghiên cứu đã được thông qua đề cương tại Hội đồng xét duyệt đề cương của trường Đại học $\mathrm{Y}$ Hà Nội.

\section{KẾT QUẢ}

\section{1. Đặc điểm đối tượng}

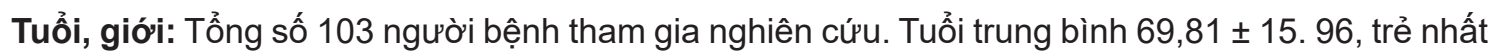
là 21 tuổi và cao tuổi nhất là 94 tuổi. Nam chiếm tỷ lệ cao hơn nữ với 64,1\% so với 35,9\%. Suy tim cấp chủ yếu gặp ở người già chiếm $74,8 \%$.

\section{Tình trạng dinh dưỡng}

Tại thời điểm nhập viện

\section{Bảng 1.Tình trạng dinh dưỡng lúc nhập viện}

\begin{tabular}{|c|c|c|c|c|}
\hline Chỉ số & Chung & Nam & Nũ & $\mathbf{p}$ \\
\hline \multirow{2}{*}{ Cân nặng (kg) } & & \multirow{2}{*}{$56,2 \pm 10,3$} & \multirow{2}{*}{$47,5 \pm 9,2$} & $p<0,05$ \\
\hline & Min:33,Max: 94 & & & (T - test) \\
\hline \multirow{2}{*}{ Chiều cao $(\mathrm{cm})$} & $158,27 \pm 7,84$ & \multirow{2}{*}{$162,5 \pm 5,1$} & \multirow{2}{*}{$150,7 \pm 5,9$} & $p<0,05$ \\
\hline & Min:140,Max:177 & & & (T - test) \\
\hline \multirow{2}{*}{$\begin{array}{l}\text { Chu vi vòng } \\
\text { cánh tay }(\mathrm{cm})\end{array}$} & 25 & \multirow{2}{*}{$25,0 \pm 3,3$} & \multirow{2}{*}{$24,0 \pm 2,8$} & $p>0,05$ \\
\hline & Min:17,Max:36 & & & Man - Whitney \\
\hline \multirow{4}{*}{ BMI chung } & $21,08 \pm 3,45$ & \multirow{2}{*}{$21,2 \pm 3,5$} & \multirow{2}{*}{$20,9 \pm 3,4$} & $p>0,05$ \\
\hline & Min:15,1;Max:34,5 & & & Chi - square \\
\hline & & & & $p>0,05$ \\
\hline & SDD $21(20,4 \%)$ & $14(21,2 \%)$ & $T(18,9 \%)$ & Fisher's Exact \\
\hline \multirow{7}{*}{$\begin{array}{l}\text { BMI nhóm } \\
\text { không phù (kg/ } \\
\text { m2) } \\
40 \text { bệnh nhân }\end{array}$} & & 21 & 20,9 & \\
\hline & Min 156 Max 30 & Min:15,6 & Min: 15,6 & $\begin{array}{c}p>0,05 \\
\text { Chi - square }\end{array}$ \\
\hline & IVIIn I5,6 IVIax: 30 & Max:30 & Max: 28 & chi - square \\
\hline & $\begin{array}{c}\text { SDD } \\
\text { (8 bệnh nhân - 20\%) }\end{array}$ & $6(22,2 \%)$ & $2(15,4 \%)$ & \multirow{4}{*}{$\begin{array}{c}p>0,05 \\
\text { Fisher's Exact }\end{array}$} \\
\hline & Bình thường (26 bệnh & & & \\
\hline & nhân - 65\%) & $18(66, / \%)$ & $8(61,5 \%)$ & \\
\hline & $\begin{array}{c}\text { Béo phì } \\
\text { (6 bệnh nhân - 15\%) }\end{array}$ & $3(11,1 \%)$ & $3(23,1 \%)$ & \\
\hline \multirow{4}{*}{$\begin{array}{l}\text { Điểm } \\
\text { mNUTRIC } \\
\text { (103 bệnh } \\
\text { nhân) }\end{array}$} & 4,0 Min:1, Max:8 & $3,8 \pm 1,6$ & $4,3 \pm 1,4$ & $p>0,05$ \\
\hline & & & & Man - Whitney \\
\hline & $\begin{array}{c}\text { Nguy cơ DD cao } \\
\text { mNutric } \geq 5\end{array}$ & $20(30,3 \%)$ & $17(45,9 \%)$ & \multirow{2}{*}{$\begin{array}{c}p>0,05 \text { Fisher's } \\
\text { Exact test }\end{array}$} \\
\hline & Nguy cơ DD thấp & $46(69,7 \%)$ & $20(54,1 \%)$ & \\
\hline
\end{tabular}


Cân nặng trung bình nam $(56,2 \pm 10,3)$ cao hơn nữ $(47,5 \pm 9,2)$, sự khác biệt này có ý nghĩa thống kê với $p>0,05$. Chiều cao trung bình nam $(162,5 \pm 5,1)$ cao hơn nữ $(150,7 \pm 5,9)$, sự khác biệt có ý nghĩa thống kê với $p>0,05$. Chu vi vòng cánh tay trung bình nam $(25 \pm 3,3)$ cao hơn nữ $(24 \pm 2,8)$, sự khác biệt không có ý nghĩa thống kê với $p>0,05$. BMI trung bình nhóm không phù ở nam $(21 \pm$ $3,3)$ thấp hơn nữ $(21,3 \pm 3,5)$, sự khác biệt không có ý nghĩa thống kê với $p>0,05$, Tỷ lệ SDD nhóm không phù nam $(22,2 \%)$ cao hơn nữ $(15,4 \%)$, tỷ lệ béo phì ở nữ $(23,1 \%)$ cao hơn nam $(11,1 \%)$ sự khác biệt không có ý nghĩa thống kê $p>0,05$. Đánh giá theo thang điểm mNutric nguy cơ dinh dưỡng cao ở nữ (45,9\%) cao hơn nam (30,3\%) sự khác biệt không có ý nghĩa thống kê với p > 0,05.

\section{Thực trạng nuôi dưỡng}

Bảng 2. Thay đổi cân nặng trung bình của người bệnh trong tuần đầu nhập viện

\begin{tabular}{lcccc}
\hline Thời điểm & $\mathbf{X} \pm \mathbf{S D}$ & Min & Max & $\mathbf{p}$ \\
\hline Ngày vào viện (103 bệnh nhân) & $53,1 \pm 10,75$ & 33 & 94 & p < 0,05 T - \\
test
\end{tabular}

Trong tuần đầu nằm viện: Cân nặng trung bình lúc nhập viện cao hơn cân nặng trung bình ngày thứ 7 nằm viện hoặc ngày ra viện. Sự khác biệt này có ý nghĩa thống kê với $p<0,05$. bệnh nhân giảm nhiều nhất $8 \mathrm{~kg}$ và tăng nhiều nhất $7,3 \mathrm{~kg}$.

Các đường nuôi ăn: Tỷ lệ bệnh nhân ăn kết hợp đường miệng và sonde dạ dày chiếm tỷ lệ cao nhất: 40,8\%. bệnh nhân chỉ ăn miệng chiếm 35,9\%. Sau đó là tỷ lệ bệnh nhân chỉ ăn qua sonde chiếm $22,3 \%$. Nuôi dưỡng sonde kết hợp với nuôi tĩnh mạch chiếm tỷ lệ thấp nhất $1 \%$. Lý do ảnh hưởng đến nuôi dưỡng liên tục: Tỷ lệ bệnh nhân gián đoạn nuôi ăn chiếm 60,2\%. Lý do gián đoạn nuôi ăn chiếm tỷ lệ cao nhất đó là tồn dư dịch dạ dày cao chiếm $56,5 \%$, do thủ thuật chiếm 43,5\%, do trào ngược 9,7\%, các nguyên nhân khác $22.5 \%$.

\section{Đánh giá khẩu phần ăn trong quá trình nằm viện}

Trung bình năng lượng thực tế trong 1 tuần điều trị

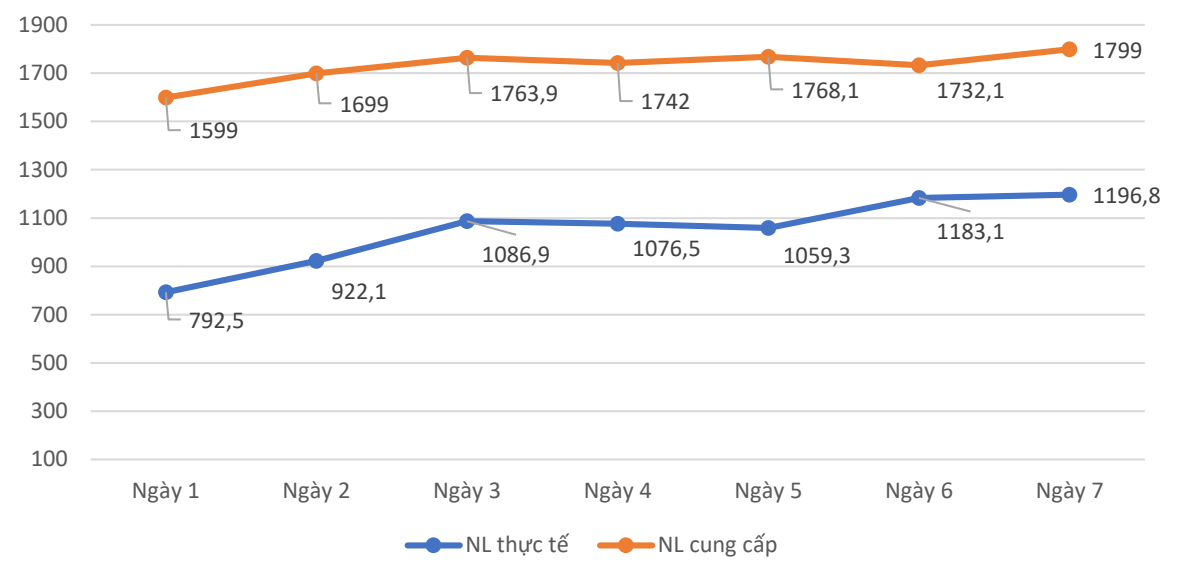

Biểu đồ 1. So sánh trung bình năng lượng thực tế đạt được và năng lượng cung cấp

Thực tế năng lượng bệnh nhân đạt được thấp hơn so với cung cấp, Ngày đầu tiên năng lượng 
thực tế chỉ đạt 49,5\% so với lượng cung cấp. Năng lượng trung bình cao nhất ngày thứ 7 cũng chỉ đạt $66,5 \%$ năng lượng cung cấp.

Bảng 3. Mức năng lượng và protein trung bình mỗi ngày theo cân nặng

\begin{tabular}{lccccc}
\hline Chỉ số & $\mathbf{N}$ & $\begin{array}{c}\text { Năng lượng } \\
\text { (Kcal/kg) }\end{array}$ & $\begin{array}{c}\text { \% Năng lượng } \\
\text { đạt được so vó́i } \\
\text { ASPEN 2016 }\end{array}$ & $\begin{array}{c}\text { Protein } \\
\mathbf{( g / k g )}\end{array}$ & $\begin{array}{c}\text { \% Protein đạt đươ'c } \\
\text { so vó́i ASPEN 2016 }\end{array}$ \\
\hline Ngày 1 & 103 & $15,2 \pm 10,1^{*}$ & $60,8 \%$ & $0,6 \pm 0,4^{*}$ & $50 \%$ \\
\hline Ngày 2 & 103 & $17,7 \pm 10,1$ & $70,8 \%$ & $0,7 \pm 0,4$ & $58,3 \%$ \\
\hline Ngày 3 & 103 & $19,6 \pm 10,2$ & $78,4 \%$ & $0,8 \pm 0,4$ & $66,7 \%$ \\
\hline Ngày 4 & 103 & $20,6 \pm 8,8$ & $82,4 \%$ & $0,84 \pm 0,4$ & $70 \%$ \\
\hline Ngày 5 & 103 & $20,2 \pm 8,8$ & $80,8 \%$ & $0,76 \pm 0,4$ & $66,7 \%$ \\
\hline Ngày 6 & 101 & $23,9 \pm 9,3^{*}$ & $95,6 \%$ & $1,01 \pm 0,48^{*}$ & $84,2 \%$ \\
\hline Ngày 7 & 99 & $22 \pm 10,4$ & $88 \%$ & $1 \pm 0,5$ & $83,3 \%$ \\
\hline
\end{tabular}

${ }^{*} p<0,05: t$ - test

Năng lượng trung trên cân nặng của bệnh nhân cao nhất vào ngày thứ $6(23,9 \pm 9,3)$, thấp nhất vào ngày đầu tiên $(15,2 \pm 10,1)$ sự khác biệt có ý nghĩa thống kê $p<0,05$. Năng lượng đạt được so với khuyến nghị ASPEN (2016) cao nhất ngày thứ 6 là 95,6\%.

Mức protein trung bình trên cân nặng của bệnh nhân cao nhất vào ngày thứ $6(1,01 \pm 0,48)$, thấp nhất vào ngày đầu tiên $(0,6 \pm 0,4)$. Sự khác biệt có ý nghĩa thống kê $p<0,05$. Trung bình protein đạt được so với ASPEN (2016) cao nhất là 84,2\%.

Bảng 4. Tỷ lệ người bệnh đạt mức năng lượng khẩu phần từ 25 - 30 kcal/kg/ngày

\begin{tabular}{lccccccc}
\hline Mú́c năng lượng & Ngày $\mathbf{1}$ & Ngày $\mathbf{2}$ & Ngày $\mathbf{3}$ & Ngày $\mathbf{4}$ & Ngày $\mathbf{5}$ & Ngày $\mathbf{6}$ & Ngày $\mathbf{7}$ \\
\hline \multirow{2}{*}{$<25 \mathrm{kcal} / \mathrm{kg} / \mathrm{ngày}$} & 85 & 78 & 73 & 73 & 78 & 68 & 59 \\
& $82,5 \%$ & $75,7 \%$ & $70,9 \%$ & $70,9 \%$ & $75,7 \%$ & $67,3 \%$ & $59,6 \%$ \\
\hline \multirow{2}{*}{25 - 30 kcal/kg/ngày } & 7 & 9 & 10 & 15 & 12 & 15 & 17 \\
& $6,8 \%$ & $8,7 \%$ & $9,7 \%$ & $14,6 \%$ & $11,7 \%$ & $14,9 \%$ & $17,2 \%$ \\
\hline \multirow{2}{*}{$>30 \mathrm{kcal} / \mathrm{kg} / \mathrm{ngày}$} & 11 & 16 & 20 & 15 & 13 & 18 & 23 \\
& $10,7 \%$ & $15,5 \%$ & $19,4 \%$ & $14,6 \%$ & $12,6 \%$ & $17,8 \%$ & $23,2 \%$ \\
\hline \multirow{2}{*}{ Tổng } & 103 & 103 & 103 & 103 & 103 & 101 & 99 \\
& $100 \%$ & $100 \%$ & $100 \%$ & $100 \%$ & $100 \%$ & $100 \%$ & $100 \%$ \\
\hline
\end{tabular}

Mức năng lượng 25 - $30 \mathrm{kcal} / \mathrm{kg} / \mathrm{ngày}$ cao nhất vào ngày thứ 7 (17,2\%). Mức năng lượng > 30 $\mathrm{kcal} / \mathrm{kg} / \mathrm{ngày}$ cao nhất vào ngày thứ $7(23,2 \%)$.

\section{BÀN LUẬN}

Tuổi, giới: Tuổi trung bình của đối tượng nghiên cứu là 71 (Min: 21,Max: 94). So sánh với các nghiên cứu suy tim khác trên thế giới độ tuổi của chúng tôi thấp hơn, như nghiên cứu OPTIMIZE - HF là $73,1 \pm 11,2 .{ }^{7}$ Độ tuổi hay gặp nhất là trên 75 tuổi chiếm $41,7 \%$ cao hơn so với nghiên cứu Nguyễn Hữu Hoan, lứa tuổi trên 75 chiếm $27 \%,{ }^{8}$ điều này cũng phù hợp với các nghiên cứu khác đã cho 
thấy rằng hầu hết các trường hợp nhập viện và tử vong liên quan đến suy tim đều ở những người > 65 tuổi. Giới: Tỷ lệ bệnh nhân nam mắc suy tim cấp là $64,1 \%$ cao hơn OPTIMIZE - HF $(49,6 \%) .{ }^{7}$ Tuy nhiên có điểm chung đó là bệnh gặp ở nam nhiều hơn ở nữ.

Tình trạng dinh dưỡng: Trong nghiên cứu chúng tôi, BMI tính chung cho tất cả tỷ lệ SDD chiếm 20,4\%, ở nhóm có phù BMI bị ảnh hưởng nhiều bởi tình trạng phù nên BMI không phản ánh đúng hết tình trạng, BMI trong nhóm không phù 21,07 (Min: 15,6; Max: 30). Tỷ lệ SDD theo BMI nhóm không phù ở nam $(22,2 \%)$ cao hơn nữ $(15,4 \%)$ sự khác biệt này không có ý nghĩa thống kê và thấp hơn Đỗ Bích Thủy với tỷ lệ SDD nam $(26,8 \%)$, nữ $(23,9 \%) .{ }^{9}$ Theo điểm mNutric thì nguy cơ dinh dưỡng cao $35,9 \%$, cao hơn nghiên cứu của Nguyễn Hữu Hoan (2016) là $27 \%,{ }^{8,10}$ sự khác biệt do tác giả trên nghiên cứu trên bệnh nhân tại ICU lần đầu vào viện, với TTDD trước đó bình thường. Vào ngày thứ 7 hoặc ngày ra viện, người giảm nhiều nhất là $8 \mathrm{~kg}$, tăng nhiều nhất là $7,3 \mathrm{~kg}$, thấp hơn Kvale (2003) ở ICU tại Norway, cho thấy $40 \%$ người bệnh mất $\geq 10 \mathrm{~kg}$ sau thời gian nằm viện $\mathrm{ICU},{ }^{11}$ sự khác biệt do thời gian theo dõi của Kvale kéo dài 6 tháng sau khi ra viện, ICU. Một yếu tố ảnh hưởng đến cân nặng là cân bằng dịch. Có nhiều yếu tố ảnh hưởng đến cân bằng dịch: như lọc máu, chọc dò màng bụng, màng phổi, phù, cổ chướng, sốt, hoặc điều trị thuốc lợi tiểu trong suy tim, tất cả đều làm ảnh hưởng đến cân nặng của người bệnh nằm ICU nói chung và ICU của tim mạch nói riêng. Tỷ lệ có nguy cơ dinh dưỡng cao tại thời điểm nhập viện là $35,9 \%$, thấp hơn Mendes và cộng sự (2017) tại ICU ở Bồ Đào Nha 48,6\%. ${ }^{12}$ Sự khác biệt này do đối tượng nghiên cứu của chúng tôi với bệnh lý về suy tim cấp, còn với tác giả Mendes và cộng sự đó là nghiên cứu quốc gia, đa trung tâm, tương lai, quan sát được thực hiện tại
15 đơn vị (ICU), trong suốt 6 tháng đối tượng người bệnh đa dạng và nhiều khoa.

Thực trạng nuôi dưỡng: Các đường nuôi ăn: Tỷ lệ bệnh nhân chỉ nuôi ăn qua ống sonde $(22,3 \%)$ cao hơn nghiên cứu của Nguyễn Hữu Hoan (2016) tại ICU là 13,5\%, nuôi ăn kết hợp sonde và tĩnh mạch(1\%) thấp hơn Nguyễn Hữu Hoan (2016) với tỷ lệ là 70,3\% \%,10 điều này là do ICU tim mạch cung cấp dinh dưỡng tĩnh mạch cần cân nhắc do dịch nuôi dưỡng ảnh hưởng lớn đến thể tích tuần hoàn, bệnh nhân suy tim cấp cần phải hạn chế dịch và dùng thuốc lợi tiểu để giảm phù.

Gián đoạn nuôi ăn: Tỷ lệ gián đoạn nuôi ăn thấp hơn nghiên cứu Nguyễn Hữu Hoan (85. 1\%). ${ }^{8,10}$ Gián đoạn nuôi ăn do tồn dư dịch dạ dày cao chiếm tỷ lệ cao nhất $(33,9 \%)$ tương tự với Nguyễn Hữu Hoan (65,3\%). ESPEN (2019) khuyến nghị nên sử dụng metoclopramide tiêm tĩnh mạch hoặc kết hợp metoclopramide và erythromycin có thể được sử dụng như một liệu pháp tăng cường vận động. ${ }^{13}$ Tại khoa ICU của viện tim mạch đa phần người bệnh tồn dư dịch dạ dày cao đáp ứng với tập phục hồi chức năng và dùng các thuốc chống trào ngược.

\section{Đánh giá khẩu phần:}

Năng lượng: Mức kcal/kg thấp nhất vào ngày đầu tiên $(15,2 \pm 10,1 \mathrm{kcal} / \mathrm{kg})$, cao nhất vào ngày thứ $6(23,9 \pm 9,3 \mathrm{kcal} / \mathrm{kg})$. Sự khác biệt có ý nghĩa thống kê với $p<0,05$. So với NCKN ASPEN (2016) thì năng lượng ngày đầu tiên chỉ đạt $60 \%$, cao nhất vào ngày thứ 6 đạt 95,6\% ${ }^{14}$ Tiêu chí sau 1 tuần sẽ đạt mức cung cấp 25 - 30kcal $/ \mathrm{kg}$ ngày phù hợp với hầu hết bệnh nhân ổn định..$^{14}$ Cũng phù hợp với NCKN ESPEN (2006) chỉ ra trong giai đoạn cấp tính và ban đầu của bệnh, cần tránh cung cấp năng lượng ngoại sinh vượt quá $20-25 \mathrm{kcal} / \mathrm{kg} /$ ngày, ngược lại, trong quá trình hồi phục, mục đích là cung cấp các giá trị từ 25 - 30 tổng kcal/ $\mathrm{kg} / \mathrm{ngày}{ }^{15}$ Năng lượng thực tế đạt được thấp 
hơn so với cung cấp cao nhất chỉ đạt $65,6 \%$ cung cấp. có rất nhiều lí do ảnh hưởng khiến bệnh nhân không ăn đủ như dự tính cung cấp. Lí do thứ nhất có thể do bệnh nhân tiến triển nặng lên, do bệnh lý của người bệnh cần làm các thủ thuật như can thiệp mạch vành, chạy thận hay các thủ thuật đặt ống nội khí quản, cấp cứu ngừng tim, và 1 phần không nhỏ đó là do tồn dư dịch dạ dày cao gây nguy cơ hít sặc do đó bệnh nhân bi gián đoạn bữa ăn. Lý do thứ 2 có thể tính đến đó là lượng bệnh nhân nặng cao, và 1 phần do chăm sóc toàn diện lại trong giai đoạn dịch Covid - 19 gặp nhiều khó khăn về nhân lực, điều dưỡng phải làm nhiều công việc cùng lúc cả chăm sóc cả cấp cứu cho bệnh nhân, vì bệnh nhân tim mạch diễn biến nhanh nhiều thủ thuật cấp cứu, khi làm nhiều việc như vậy có thể dẫn đến bệnh nhân không được cho ăn đúng với thời điểm ghi chép trên bệnh án.

Protein: Protein thấp nhất vào ngày đầu tiên $(31 \pm 18,6 \mathrm{~g})$, cao nhất vào ngày thứ 6 $(52,3 \pm 37,1 \mathrm{~g})$. Kết quả này tương tự với tác giả Nguyễn Thị Trang (2018) với protein trung bình thấp nhất vào ngày thứ $2(35,5 \pm 35,1 \mathrm{~g})$, cao nhất vào ngày thứ $5(52,8 \pm 24,2 \mathrm{~g}) .{ }^{16}$ Mức Protein $/ \mathrm{kg}$ thấp nhất vào ngày đầu tiên $(0,6 \pm$ $0,35 \mathrm{~g} / \mathrm{kg})$,cao nhất vào ngày thứ $6(1,1 \pm 1,48 \mathrm{~g} /$ $\mathrm{kg}$ ) kết quả này thấp hơn NCKN của ASPEN là $1,2-2 \mathrm{~g} / \mathrm{kg} / \mathrm{ngày}{ }^{14}$ và ESPEN (2019) là $1,3 \mathrm{~g} / \mathrm{kg} /$ ngày. ${ }^{13}$

Tỷ lệ bệnh nhân nuôi ăn đủ mức năng lượng khuyến nghị của ASPEN (2016): Số bệnh nhân đạt 25 - $30 \mathrm{kcal} / \mathrm{kg} / \mathrm{ngày}$ thấp hơn nghiên cứu của Nguyễn Hữu Hoan với tỷ lệ ăn đạt lần lượt là ngày thứ 2 có $21,2 \%$, ngày thứ 4 có $25,4 \%$, ngày thứ 7 có $21.1 \%$ người ăn đạt NCKN. ${ }^{8}$ Điều này được lý giải do nhóm bệnh nhân nghiên cứu với bệnh lý suy tim cấp phải điều trị hồi sức sử dụng các thuốc vận mạch (42 người), tình trạng nặng nên dung nạp thức ăn kém hơn. Điều này cũng phù hợp với các khuyến cáo đưa ra rằng khẩu phần ăn đường tiêu hóa cần được tăng dần đến mức đạt NCKN sau 1 tuần nằm viện.

\section{Hạn chế của nghiên cứu:}

Hạn chế của nghiên cứu này đó là việc xác định nhu cầu năng lượng chính xác cho bệnh nhân khi không có thiết bị đo tiêu hao năng lượng chuyên dụng, việc xác định cân nặng bệnh nhân dưa vào đó để ước tính nhu cầu năng lượng cũng bị ảnh hưởng bởi tình trạng sung huyết trong giai đoạn cấp của suy tim. Có thể dùng máy đo chuyển hóa năng lượng gián tiếp (Indirect Caloriemetry - IC) để xác định tiêu hao năng lượng lúc nhằm tránh biến chứng do dinh dưỡng thiếu hoặc thừa, tăng nguy cơ biến chứng do dinh dưỡng. Trường hợp không có máy $\mathrm{IC}$, có thể dùng công thức dựa trên cân nặng $(\mathrm{CN})$ để xác định nhu cầu dinh dưỡng tuy nhiên hiện nay ở BV Bạch Mai chỉ có 1 máy đo duy nhất tại khoa cấp cứu A9. Cách đo này chưa phổ cập được vì tốn kém nên hầu hết ở các khoa tính năng lượng dựa trên cân nặng của bệnh nhân và khẩu phần ăn. Nhu cầu năng lượng ước tính tùy thuộc vào tuổi giới và tình trạng bệnh lý. năng lượng tiêu hao lúc nghỉ tốt nhất đo IC hoặc ước tính dựa trên phương trình 20 - 30kcal/kg/ ngày. ${ }^{17}$ Một hạn chế nữa đó là việc cho ăn ở bệnh nhân phải đặt sonde dạ dày không thực hiện bằng dây truyền nhỏ giọt mà thực hiện bằng bơm tay qua xilanh cũng ảnh hưởng nhiều đến hiệu quả nuôi dưỡng. Trong nghiên cứu này chúng tôi gặp một số hạn chế như không thể xác định cân nặng chính xác của bệnh nhân khi phù do đối tượng chúng tôi là bệnh nhân suy tim cấp, cân nặng bị ảnh hưởng bởi lượng dịch do chức năng tim bị suy giảm và có nhiều bệnh kèm theo gây, ứ dịch làm bệnh nhân có cân nặng tăng ảo, ảnh hưởng đến việc xác định tình trạng dinh dưỡng theo BMI của 
bệnh nhân. Và cũng chưa có một cách tính tối ưu nào về $\mathrm{BMI}$ cho đối tượng bị phù

\section{KÉT LUÂN}

Tình trạng dinh dưỡng của bệnh nhân suy tim cấp tại Viện Tim Mạch Việt Nam : Tỷ lệ SDD tại thời điểm nhập viện theo BMI chung 20,4\%, nhóm không phù là 20\% (tỷ lệ SDD nam $22,2 \%$, nữ là 15,4\%). Theo điểm mNUTRIC, tỷ lệ nguy cơ dinh dưỡng cao tại thời điểm nhập viện là 35,9\%. Cân nặng ở thời điểm ngày ra viện hoặc ngày thứ 7 thấp hơn so với thời điểm nhập viện có ý nghĩa thống kê, với $p<0,05$.

Thực trạng nuôi dưỡng bệnh nhân suy tim cấp tại Viện Tim Mạch Việt Nam. Bệnh nhân được nuôi ăn bằng đường miệng kết hợp sonde dạ dày là phổ biến nhất, chiếm 40,8\%, phối hợp sonnde và đường tĩnh mạch hoàn toàn là $1 \%$. Gián đoạn nuôi ăn chiếm $60,2 \%$, lý do gián đoạn nuôi ăn chiếm tỷ lệ cao nhất đó là tồn dư dịch dạ dày cao chiếm 33,9\%. Về khẩu phần: Năng lượng thực tế đạt được cao nhất chỉ chiếm $66,5 \%$ cung cấp. Tỷ lệ bệnh nhân đạt mức năng lượng 25 - $30 \mathrm{kcal} / \mathrm{kg} / \mathrm{ngày}$ thấp nhất vào ngày đầu tiên chiếm $6,8 \%$, cao nhất vào ngày thứ 7 chiếm $17,2 \%$.

\section{Khuyến nghị}

Đối với khoa : Cần có sự phối hợp chặt chẽ giữa điều dưỡng, bác sĩ điều trị trong đánh giá dinh dưỡng cho bệnh nhân ICU tim mạch bằng thang điểm NUTRIC kết hợp với chuyên khoa dinh dưỡng để có giải pháp phù hợp. Đối với bệnh nhân sau rút ống nội khí quản, có tình trạng ăn kém, cần xem xét chế độ dinh dưỡng bổ sung sau rút ống hoặc xem xét nuôi sonde nếu bệnh nhân không ăn được.

Đối với các nghiên cứu tiếp theo: Nghiên cứu tiếp theo cần đi sâu tìm hiểu các biện pháp can thiệp để cải thiện tình trạng dinh dưỡng của nhóm bệnh nhân này.

\section{TÀI LIẸU THAM KHẢO}

1. Ponikowski $P$ VA, Anker $S D$ và các cộng sự. (2016). ESC Guidelines for the diagnosis and treatment of acute and chronic heart failure: The Task Force for the diagnosis and treatment of acute and chronic heart failure of the European Society of Cardiology (ESC) Developed with the special contribution of the Heart Failure Association (HFA) of the ESC. 2016.

2. Dickstein K, Cohen - Solal A, Filippatos $G$, et al. ESC Guidelines for the diagnosis and treatment of acute and chronic heart failure 2008: the Task Force for the Diagnosis and Treatment of Acute and Chronic Heart Failure 2008 of the European Society of Cardiology. Developed in collaboration with the Heart Failure Association of the ESC (HFA) and endorsed by the European Society of Intensive Care Medicine (ESICM). European heart journal. 2008;29(19):2388 - 2442.

3. Lassus JP, Siirila - Waris K, Nieminen MS, et al. Long - term survival after hospitalization for acute heart failure - - differences in prognosis of acutely decompensated chronic and new onset acute heart failure. International journal of cardiology. 2013;168(1):458 - 462.

4. Farmakis D, Parissis J, Lekakis J, Filippatos G. Acute heart failure: epidemiology, risk factors, and prevention. Revista Española de Cardiología (English Edition). 2015;68(3):245 $-248$.

5. Agra Bermejo RM, Gonzalez Ferreiro $R$, Varela Roman A, et al. Nutritional status is related to heart failure severity and hospital readmissions in acute heart failure. International journal of cardiology. 2017;230:108 - 114.

6. Benítez Brito N, Suárez Llanos JP, Fuentes Ferrer $\mathrm{M}$, et al. Relationship between mid upper arm circumference and body mass index in inpatients. PloS one. 2016;11(8):e0160480. 
7. Fonarow GC, Abraham WT, Albert $\mathrm{NM}$, et al. Factors identified as precipitating hospital admissions for heart failure and clinical outcomes: findings from OPTIMIZE - HF. Archives of internal medicine. 2008;168(8):847 - 854.

8. Nguyễn Hữu Hoan. Tình trạng dinh dưỡng và thực trạng nuôi dưỡng bệnh nhân tại khoa điều trị tích cực Bệnh viện Bạch Mai năm 2015. Luận văn thạc sĩ Y học, Trường Đại học Y Hà Nội; 2016.

9. Đỗ Bích Thủy. Tình trạng dinh dưỡng, khẩu phần ăn thực tế của người bệnh suy tim tại bệnh viện Tim Hà Nội Luận văn Thạc Sỹ Y Học: dinh dưỡng, Trường Đại học Y Hà Nội; 2018.

10. Nguyễn Hưu Hoan. Tình trạng dinh dưỡng và thực trạng nuôi dưỡng bệnh nhân tại khoa điều trị tích cực Bệnh viện Bạch Mai năm 2015. Hà Nội: Luận văn thạc sĩ y học, Trường đại học Y Hà Nội; 2016.

11. Kvåle R, Ulvik A, Flaatten H. Follow up after intensive care: a single center study. Intensive care medicine. 2003;29(12):2149 2156.

12. Mendes R, Policarpo S, Fortuna P, et al. Nutritional risk assessment and cultural validation of the modified NUTRIC score in critically ill patients-a multicenter prospective cohort study. Journal of critical care. 2017;37:45 $-49$.

13. Singer $P$, Blaser $A R$, Berger $M M$, et al. ESPEN guideline on clinical nutrition in the intensive care unit. Clinical nutrition. 2019;38(1):48 - 79.

14. McClave SA, Taylor BE, Martindale $R G$, et al. Guidelines for the Provision and Assessment of Nutrition Support Therapy in the Adult Critically III Patient: Society of Critical Care Medicine (SCCM) and American Society for Parenteral and Enteral Nutrition (A. S. P. E. N. ). JPEN J Parenter Enteral Nutr. 2016;40(2):159 $-211$.

15. Kreymann K, Berger M, Deutz Ne, et al. ESPEN guidelines on enteral nutrition: intensive care. Clinical nutrition. 2006;25(2):210 - 223.

16. Nguyễn Thị Trang. Tình trạng dinh dưỡng và thực trạng nuôi dưỡng người bệnh tại khoa hồi sức tích cực bệnh viện Lão Khoa Trung Ương năm 2017. Luận văn Thạc sĩ Y Học, Trường đại học Y Hà Nội; 2018.

17. Lưu Ngân Tâm (2019). Hướng dẫn dinh dương trong điều trị bệnh nhân nặng. Nhà xuất bản Y học 2019.

\section{Summary}

\section{NUTRITIONAL STATUS AND DIETARY INTAKE OF PATIENTS WITH ACUTE HEART FAILURE AT THE VIETNAM HEART INSTITUTE IN 2020}

The nutritional status of patients with acute heart failure affects their treatment and dietary support in the hospital. Among 103 in-patients, $20.4 \%$ have malnutrition according to the general BMI; $20 \%$ of acute heart failure patients without edema are malnourrished (male $22.2 \%$ higher than female $15.4 \%$ ). While the rate of malnutrition according to the NUTRIC scale was $35.9 \%$, the high risk rate in men $(30.3 \%)$ is lower than in women $(45.9 \%)$ the difference is not statistically significant $(p$ $<0.05$ ). During the first week of admission for treatment, the maximum weight loss was $8 \mathrm{~kg}$ and the maximum weight gain was $7.3 \mathrm{~kg}$. There was $60.2 \%$ of patients with diet intake interruption. The main and highest recorded reason was high gastric residual $(33.9 \%)$, followed by procedurerelated effects $(26.2 \%)$. The highest caloric intake attained was at $66.5 \%$ of the recommended daily 
allowance. Only $6.8 \%$ of patients can reached $25-30 \mathrm{kcal} / \mathrm{kg} /$ day on the first day of hospitalization, which increased to $17.2 \%$ patients on the 7 th day of hospitalization. Patients' nutritional status, dietary intake and feeding disruption must be attentively evaluated for timely intervention. Keywords: acute heart failure, malnutrition, BMI, Nutric score. 